DOI. 10.22219/fths.v4i2.16595

Received: 23 Mei 2021

Accepted: 25 Juni 2021

Available online: 30 Juni 2021

\title{
Pengaruh Waktu dan Suhu Pengeringan Menggunakan Pengering Kabinet dalam Pembuatan MOCAF (Modified Cassava Flour) dengan Fermentasi Ragi Tape
}

\author{
Aisah $^{1 *}$, Noor Harini ${ }^{1}$, Damat ${ }^{1}$ \\ ${ }^{1}$ Program Studi Teknologi Pangan, Fakultas Pertanian Peternakan, Universitas Muhammadiyah \\ Malang, Malang, Indnesia. \\ *Corresponding author email: aisahwa03@gmail.com
}

\begin{abstract}
The purpose of this study, to see the interaction of the effect of drying time and temperature of the carbohydrate content of carbohydrates, the interaction of the effect of coordinated time and temperature on mocaf, and the effect of time and optimal drying temperature of mocaf. The study used a factorial randomized block design with a factor of 1 , namely the drying time (8 hours, 12 hours, 24 hours) and factor 2, namely the drying temperature $\left(50^{\circ} \mathrm{C}, 70^{\circ} \mathrm{C}, 80^{\circ} \mathrm{C}\right)$. The preliminary stage of this research is soaking the cassava chips with 5\% salt. The next step is making yeast fermentation mocaf with drying time and temperature treatment using a cabinet dryer. The parameters analyzed were moisture content, ash content, fat content, protein content, carbohydrate content, and color content. The results showed that the treatment of drying time of 8 hours and drying temperature of $70^{\circ} \mathrm{C}$ is the best treatment measured by the De Garmo test. The test results showed that the treatment had a water content of $10.08 \%$, a protein content of $0.73 \%$, a fat content of $0.06 \%$, an ash content of $8.35 \%$, carbohydrate content of $80.75 \%$, a brightness level $(L)$ is -11.6 , the level of redness $(a+)$ is 3.85, and the level of yellowness $(b+)$ is 9.3.
\end{abstract}

Keywords: Drying Temperature, Drying Time, Modified Cassava Flour, Yeast Tape Fermentation

\begin{abstract}
Abstrak. Tujuan penelitian ini, untuk mengetahui interaksi pengaruh perlakuan waktu dan suhu pengeringan terhadap kadar karbohidrat mocaf, mengetahui interaksi pengaruh perlakuan waktu dan suhu pengeringan terhadap kecerahan mocaf dan mengetahui interaksi pengaruh waktu dan suhu pengeringan mocaf yang optimal. Penelitian ini menggunakan Rancangan Acak Kelompok Faktorial (RAK Faktorial) dengan faktor 1 yaitu perlakuan waktu pengeringan ( $8 \mathrm{jam}, 12 \mathrm{jam}, 24 \mathrm{jam}$ ) serta faktor 2 yaitu suhu pengeringan $\left(50^{\circ} \mathrm{C}, 70^{\circ} \mathrm{C}, 80^{\circ} \mathrm{C}\right)$. Tahap pendahuluan penelitian ini adalah perendaman chips singkong dengan $5 \%$ garam. Tahap selanjutnya adalah pembuatan mocaf fermentasi ragi tape dengan perlakuan waktu dan suhu pengeringan menggunakan pengering kabinet. Parameter yang dianalisis yaitu kadar air, kadar abu, kadar lemak, kadar protein, kadar karbohidrat dan kadar warna. Hasil Penelitian menunjukkan perlakuan waktu pengeringan 8 jam dan suhu pengeringan $70^{\circ} \mathrm{C}$ merupakan perlakuan terbaik yang diukur dengan uji De Garmo. Hasil uji menunjukkan bahwa perlakuan tersebut memiliki kadar air sebesar 10,08\%, kadar
\end{abstract}


protein sebesar 0,73\%, kadar lemak sebesar 0,06\%, kadar abu sebesar 8,35\%, kadar karbohidrat sebesar 80,75\%, tingkat keceraha (L) sebesar -11,6, tingkat kemerahan $(\mathrm{a}+)$ sebesar 3,85, serta tingkat kekuningan $(b+)$ sebesar 9,3.

Kata kunci: Fermentasi Ragi Tape, Modified Cassava Flour, Suhu Pengeringan, Waktu Pengeringan

\section{PENDAHULUAN}

Singkong termasuk dalam tanaman pangan berupa tanaman perdu yang memiliki nama lain ubi kayu, ketela pohon, kasape dan telo kaspo. Singkong diperkirakan masuk ke Indonesia pada tahun 1852. Asal negara singkong dari negara Brazil, tepatnya di benua Amerika. Pesebaran singkong pada beberapa negara, antara lain Afrika, India, Madagaskar dan Tiongkok (Rahmawati, 2010).

Keunggulan ragi tape yaitu mengandung berbagai kelompok mikroorganisme yang dapat mengubah karbohidrat (pati) menjadi gula sederhana (glukosa). Ragi tape merupakan kultur kering yang terdiri dari konsorsium mikroba berupa yeast atau khamir, kapang (Mucor, Rhizopus dan Amylomyces) dan bakteri dengan jenis cocci. Kapang yang terdapat pada ragi tape merupakan jenis kapang yang diketahui mempunyai kemampuan untuk menghasilkan enzimenzim amilolitik. Penggunaan ragi tape dalam proses pembuatan tape juga mempunyai keuntungan harganya murah dan mudah didapatkan, sehingga memungkinkan untuk diaplikasikan dimasyarakat (Arnata dkk., 2013).

Pentingnya pengeringan dalam pembuatan MOCAF dikarenakan mempunyai syarat kadar air maksimal sebesar $13 \%$, oleh karena itu pembuatan mocaf sangat bergantung pada proses pengeringan. Metode pengeringan yang biasanya digunakan ialah pengeringan secara tradisional dengan memanfaatkan panas matahari. Pengeringan menggunakan panas matahari sangat bergantung pada kondisi cuaca, sehingga mutu produk mocaf yang dihasilkan tidak dapat terkontrol. Metode pengeringan dengan panas matahari dapat diatasi dengan menggunakan pengering kabinet. Pengeringan menggunakan pengering kabinet dapat mengatur waktu dan suhu pengeringan, sehingga mutu produk akhir dapat terkontrol. Penggunaan pengering kabinet untuk mengeringkan dapat berjalan lebih baik dan cepat. Berdasarkan hasil peneliti sebelumnya yakni Farel (2012), melakukan penelitian dan pengujian tentang alat pengering kakao tipe pengering cabinet dan mampu mengeringkan bahan dari kadar air sekitar 51\% - 60\% menjadi $6,450 \%$ sampai $7,315 \%$. 


\section{METODE PENELITIAN}

\section{Bahan}

Bahan utama yang digunakan dalam penelitian ini adalah ubi kayu umur panen 8-11 bulan yang diperoleh di Pasar Landungsari. Bahan pendukung dalam penelitian ini adalah garam dapur (Cap Kapal), ragi tape (Na Kok Liong) dan air. Bahan kimia yang digunakan adalah reagen biuret, aquades, $\mathrm{HCl}$ p.a, etanol $96 \%$, petroleum benzine p.a, Bovine Serum Albumine (BSA) p.a dan alumunium foil.

Alat

Alat-alat yang digunakan dalam pembuatan mocaf adalah pisau, baskom, talenan, timbangan analitik (Poneer Ohaus PA 413), pengering kabinet, ayakan 60 mesh. Alat-alat yang digunakan untuk analisis adalah tabung reaksi, rak tabung reaksi, cawan krusibel, desikator, Soxhlet (Gerhardt IPEV 16 Germany), color reader (Konica Minolta CR-10 Plus), labu reaksi, labu ukur, gelas ukur, corong, gelas beker, oven, waterbath (Memmert), pipet ukur, labu lemak, mesin penepung (Disk Mill FFC-15-1).

\section{Desain Penelitian}

Rancangan penelitian yang digunakan pada penelitian ini adalah Rancangan Acak Kelompok (RAK) Faktorial yang disusun menjadi 2 faktor. Faktor I yaitu perlakuan waktu pengeringan (W) yang digunakan, sedangkan faktor II adalah suhu pengeringan (S). Kombinasi perlakuan diperoleh sebanyak 9 perlakuan dengan 2 kali ulangan.

\section{Prosedur Penelitian}

Ubi kayu segar dibersihkan dari tanah dan kotoran dengan cara dicuci dalam keadaan belum terkupas. Sekali percobaan dibutuhkan ubi kayu sekitar 4,5-5 Kg untuk menghasilkan irisan ubi kayu seberat $4 \mathrm{Kg}$. Ubi kayu dikupas setelah dibersihkan. Semua ubi kayu yang telah dikupas dan dicuci bersih, dikecilkan ukurannya.

Tahap fermentasi dilakukan dengan cara irisan singkong direndam dahulu dalam larutan garam dapur 5\%, selama 6 jam. Singkong yang telah dikecilkan ukurannya difermentasi menggunakan ragi tape dengan konsentrasi $5 \%$ selama 3 hari. Singkong kemudian dikeringkan di dalam pengering kabinet dengan perlakuan suhu $50^{\circ} \mathrm{C} \pm 5^{\circ} \mathrm{C}, 70^{\circ} \mathrm{C} \pm 5^{\circ} \mathrm{C}, 80^{\circ} \mathrm{C} \pm 5^{\circ} \mathrm{C}$ dan lama waktu pengeringan 8 jam, 12 jam dan 24 jam. Singkong kering yang dihasilkan kemudian dihaluskan hingga membentuk tepung menggunakan alat penepung. Kemudian tepung dilakukan pengayakan. 


\section{Parameter Peenelitian}

Parameter yang dianalisis yaitu kadar protein (Purwanto, 2014), kadar lemak (SNI, 1992), kadar abu (Sudarmadji dkk., 2007), kadar air (Sudarmadji dkk., 2007), penghitungan karbohidrat (SNI, 1992) dan analisa warna (KONICA MINOLTA, INC. 2015).

\section{Analisis Data}

Data yang didapat dianalisis menggunakan analisa sidik ragam (ANOVA) dengan uji $\mathrm{F}$ pada taraf $5 \%$. Bila terjadi berpengaruh nyata atau interaksi pada masing-masing perlakuan maka data yang diperoleh akan dilanjutkan dengan uji pembeda menggunakan uji DMRT (Duncan's Multiple Range Test) pada Microsoft Excel 2007. Penentuan perlakuan terbaik menggunakan metode De Garmo (1984).

\section{HASIL DAN PEMBAHASAN}

\section{Kadar Air}

Berdasarkan hasil analisis ragam menunjukkan bahwa terjadi interaksi antara waktu dan suhu pengeringan terhadap kadar air mocaf. Perlakuan waktu dan suhu pengeringan tidak berpengaruh nyata terhadap kadar air mocaf yang dihasilkan. Rerata kadar air akibat perlakuan waktu dan suhu engeringan yang berbeda dapat dilihat pada Tabel 1 .

Tabel 1. Kadar Air Mocaf dengan Fermentasi Ragi Tape Akibat Interaksi antara Waktu dan Suhu Pengeringan dengan Pengering Kabinet

\begin{tabular}{|c|c|}
\hline Waktu dan Suhu Pengeringan & Kadar Air (\%) \\
\hline W1S1 (Waktu 8 jam + Suhu $\left.50^{\circ} \mathrm{C}\right)$ & $13,37^{\mathrm{gh}}$ \\
\hline W2S1 (Waktu 12 jam + Suhu $\left.50^{\circ} \mathrm{C}\right)$ & $12,78^{\mathrm{ef}}$ \\
\hline W3S1 (Waktu 24 jam + Suhu $\left.50^{\circ} \mathrm{C}\right)$ & $12,19^{\mathrm{cd}}$ \\
\hline W1S2 (Waktu 8 jam + Suhu $\left.70^{\circ} \mathrm{C}\right)$ & $10,08^{\mathrm{a}}$ \\
\hline W2S2 (Waktu 12 jam + Suhu $\left.70^{\circ} \mathrm{C}\right)$ & $10,16^{\mathrm{ab}}$ \\
\hline W3S2 (Waktu 24 jam + Suhu $\left.70^{\circ} \mathrm{C}\right)$ & $14,24^{\mathrm{h}}$ \\
\hline W1S3 (Waktu 8 jam + Suhu $\left.80^{\circ} \mathrm{C}\right)$ & $12,75^{\text {de }}$ \\
\hline W2S3 (Waktu 12 jam + Suhu $80^{\circ} \mathrm{C}$ ) & $11,61^{\mathrm{bc}}$ \\
\hline W3S3 (Waktu 24 jam + Suhu $80^{\circ} \mathrm{C}$ ) & $12,93^{\text {fg }}$ \\
\hline
\end{tabular}

Keterangan : Nilai rata-rata yang diikuti oleh huruf yang sama menunjukkan tidak berbeda nyata dengan uji Duncan 5\%.

Berdasarkan hasil yang ditampilkan pada Tabel 1 menunjukkan, bahwa kadar air terendah pada mocaf fermentasi ragi tape perlakuan waktu pengeringan 8 jam dan suhu pengeringan $70^{\circ} \mathrm{C}$ (10,18\%), dan kadar air tertinggi pada perlakuan waktu pengeringan 24 jam dan suhu pengeringan $70^{\circ} \mathrm{C}(14,24 \%)$. Ratarata kadar air tepung mocaf fermentasi ragi tape menggunakan pengering kabinet berkisar antara 10,08-14,2\%. Hasil kadar air apabila dibandingkan dengan SNI 
(2011), beberapa memenuhi standar mutu yang ditetapkan. Syarat mutu kadar air tepung mocaf adalah maksimal $13 \%$.

Hasil penelitian ini lebih rendah dari penelitian sebelumnya yakni Lubis dkk. (2012) yang melaporkan bahwa kadar air pada pembuatan produk meuseukat sebesar $34,30 \%$. Hal itu dapat disebabkan oleh adanya penambahan tepung komposit dari suku dan terigu serta penambahan nanas. Menurut Suprapti (2001) menyatakan bahwa kandungan air pada nenas mempengaruhi kadar air pada meuseukat yang dihasilkan karena semakin banyak nanas yang ditambahkan maka kandungan air di dalam adonan juga akan bertambah. Bila dilihat dari komposisi kimia yang terkandung dalam buah nenas ternyata kandungan air merupakan komposisi terbesar yaitu sekitar $85,30 \%$.

Penurunan kadar air mocaf fermentasi ragi tape sangat diperlukan, mengingat kadar air dapat mempengaruhi proses penyimpanan tepung. Menurut Taufiq (2004) yang menyatakan bahwa semakin besar temperatur pengeringan maka laju pengeringan akan semakin meningkat. Hal tersebut disebabkan makin tinggi suhu udara pengering maka semakin tinggi energi panas yang dibawa udara, sehingga semakin banyak jumlah massa cairan yang diuapkan dari permukaan bahan. Menurut Joko dkk. (2012) menyatakan bahwa semakin tinggi suhu udara pengering yang diberikan, maka perbedaan tekanan uap antara udara dengan tekanan uap pada bahan akan semakin besar. Proses perpindahan uap air dari dalam bahan menuju udara sekeliling akan menjadi lebih cepat.

Hal ini menunjukkan bahwa semakin lama waktu pengeringan maka kadar air yang terdapat pada bahan semakin sedikit. Menurut Lisa dkk. (2015) kemampuan bahan dalam melepaskan air dari permukaannya akan semakin besar seiring dengan bertambahnya waktu pengeringan. Menurut Muntikah dkk. (2017) menyatakan bahwa keuntungan pengeringan adalah bahan menjadi lebih awet dan volume bahan menjadi lebih kecil sehingga mempermudah dan menghemat ruang pengangkutan dan pengepakan, berat bahan juga menjadi berkurang sehingga memudahkan transpor, dengan demikian di harapkan biaya produksi menjadi lebih murah. Kecuali itu, banyak bahan-bahan yang hanya dapat di pakai apabila telah di keringkan, misalnya tembakau, kopi, teh, dan bijibijian.

Pengecilan ukuran berfungsi untuk memperluas permukaan bahan. Menurut O'Kelly dkk. (2004) menyatakan bahwa luas permukaan bahan yang tinggi atau ukuran bahan yang semakin kecil menyebabkan permukaan yang dapat komtak dengan medium pemanas menjadi lebih baik, luas permukaan yang tinggi juga menyebabkan air lebih mudah berdifusi atau menguap dari bahan pangan, sehingga kecepatan penguapan air lebih cepat dan bahan menjadi lebih cepat kering.

Penetapan kandungan air dapat dlakukan dengan beberapa cara. Menurut Winarno (2004) menyatakan bahwa hal tersebut bergantung pada sifat bahannya. 
Pada umumnya penentuan kadar air dilakukan dengan mengeringkan bahan

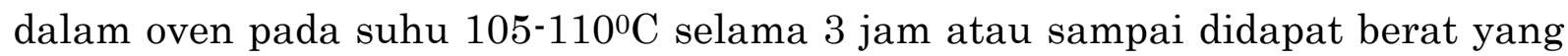
konstan. Selisih berat sebelumnya dan sesudah pengeringan adalah banyaknya air yang diuapkan. Untuk bahan-bahan yang tidak tahan panas, seperti bahan berkadar gula tinggi, minyak, daging, kecap, dan lain, pemanasan dilakukan dalam oven vakum dengan suhu yang lebih rendah.

\section{Kadar Abu}

Berdasarkan analisis ragam menunjukkan bahwa terjadi interaksi antara suhu dan waktu pengeringan terhadap kadar abu mocaf fermentasi ragi tape. Analisis suhu dan waktu pengeringan tidak menunjukkan perbedaan nyata terhadap kadar abu yang dihasilkan. Rerata kadar abu akibat perlakuan waktu dan suhu pengeringan yang berbeda dapat dilihat pada Tabel 2 .

Tabel 2. Kadar Abu Mocaf dengan Fermentasi Ragi Tape Akibat Interaksi antara Waktu dan Suhu Pengeringan dengan Pengering Kabinet

\begin{tabular}{|c|c|}
\hline Waktu dan Suhu Pengeringan & Kadar Abu (\%) \\
\hline W1S1 (Waktu 8 jam + Suhu $\left.50^{\circ} \mathrm{C}\right)$ & $6,32^{\mathrm{a}}$ \\
\hline W2S1 (Waktu 12 jam + Suhu $50^{\circ} \mathrm{C}$ ) & $8,35^{\mathrm{a}}$ \\
\hline W3S1 (Waktu 24 jam + Suhu $50^{\circ} \mathrm{C}$ ) & $6,83^{\mathrm{a}}$ \\
\hline W1S2 (Waktu 8 jam + Suhu $\left.70^{\circ} \mathrm{C}\right)$ & $5,43^{\mathrm{a}}$ \\
\hline W2S2 (Waktu 12 jam + Suhu $70^{\circ} \mathrm{C}$ ) & $6,52^{\mathrm{a}}$ \\
\hline W3S2 (Waktu 24 jam + Suhu $\left.70^{\circ} \mathrm{C}\right)$ & $6,85^{\mathrm{a}}$ \\
\hline W1S3 (Waktu 8 jam + Suhu $\left.80^{\circ} \mathrm{C}\right)$ & $7,20^{\mathrm{a}}$ \\
\hline W2S3 (Waktu 12 jam + Suhu $80^{\circ} \mathrm{C}$ ) & $4,66^{\mathrm{a}}$ \\
\hline W3S3 (Waktu 24 jam + Suhu $80^{\circ} \mathrm{C}$ ) & $7,25^{\mathrm{a}}$ \\
\hline
\end{tabular}

Keterangan : Nilai rata-rata yang diikuti oleh huruf yang sama menunjukkan tidak berbeda nyata dengan uji Duncan 5\%.

Berdasarkan Tabel 2 tersebut didapatkan hasil bahwa kadar abu perlakuan suhu $50^{\circ} \mathrm{C}$ yaitu $6,32 \%$. Perlakuan suhu $70^{\circ} \mathrm{C}$ yaitu $6,51 \%$. Perlakuan suhu $80^{\circ} \mathrm{C}$ memiliki kadar abu yaitu 6,98\%. Hasil penelitian ini apabila dibandingkan dengan SNI (2011), belum memenuhi standar mutu yang ditetapkan. Syarat mutu kadar abu tepung mocaf adalah $1,5 \%$.

Hasil ini kurang sesuai dengan penelitian sebelumnya, yakni Rijal dkk. (2019) bahwa pengaruh suhu dan lama pengeringan terhadap tepung umbi talas didapatkan kadar abu sebanyak 11,46\%. Hal tersebut dapat dipengaruhi oleh tingkat kematangan umbi. Menurut Amanu dkk. (2014) menyatakan bahwa pektin berbeda-beda pada tingkat kematangan buah, buah yang matang mengandung asam pektat yang merupakan degradasi dari pektin. Ion kalsium dan magnesium yang terlepas akibat pemanasan dan $\mathrm{pH}$ tinggi dari buah matang. Hidrolisis protopektin menyebabkan bertambahnya kandungan kalsium dan magnesium. Selama proses pemanasan, air mempunyai tingkat kesadahan yang tingg sehingga menambah jumlah mineral dalam produk. 
Semakin tinggi suhu yang digunakan maka semakin tinggi pula kadar abu yang dihasilkan. Hal tersebut sesuai dengan pernyataan Asrawaty (2011) yang menyatakan bahwa peningkatan kadar abu ini terjadi karena semakin lama waktu dan semakin tinggi suhu pengeringan maka akan semakin banyak air yang teruapkan dari bahan yang dikeringkan. Menurut Lidiasari dkk. (2006) menyatakan bahwa tepung sudah mengalami proses fermentasi, sehingga banyak protein yang terhidrolisis. Protein gabungan dari pangan pada hidrolisis dapat menghasilkan logam, karbohidrat, fosfat dan lipida, sehingga lebih banyak protein yang terhidrolisis maka lebih banyak logam yang terbentuk. Selaras dengan Ambarsari dkk. (2009) yang menyatakan bahwa tingginya kadar abu pada suatu produk menunjukkan tingginya kandungan mineral.

Kadar abu merupakan parameter untuk menunjukan nilai kandungan bahan anorganik (mineral) yang ada di dalam suatu bahan atau produk. Menurut Sudarmaji (2003) menyatakan bahwa komponen anorganik di dalam suatu bahan sangat bervariasi baik jenis maupun jumlahnya. Kandungan bahan anorganik yang terdapat di dalam suatu bahan diantaranya kalsium, kalium, fosfor, besi, dan magnesium. Proses pengeringan mengakibatkan terjadinya penguraian komponen ikatan molekul air (H2O) dan juga memberikan peningkatan terhadap kandungan gula, lemak, mineral, sehingga mengakibatkan terjadinya peningkatan kadar abu.

\section{Kadar Lemak}

Berdasarkan analisis ragam menunjukkan bahwa terjadi interaksi antara waktu dan suhu pengeringan dengan pengeing cabinet terhadap kadar lemak yang dihasilkan. Perlakuan waktu dan suhu pengeringan dengan pengering cabinet tidak berpengaruh nyata terhadap kadar lemak yang dihasilkan. Rerata kadar lemak akibat pengaruh waktu dan suhu pengeringan dengan pengering cabinet dapat dilihat pada Tabel 3.

Tabel 3. Kadar Lemak Tepung Mocaf dengan Fermentasi Ragi Tape Akibat Interaksi Antara Waktu dan Suhu Pengering dengan Pengering Kabinet

\begin{tabular}{|c|c|}
\hline Suhu dan Waktu Pengeringan & Lemak (\%) \\
\hline W1S1 (Waktu 8 jam + Suhu $\left.50^{\circ} \mathrm{C}\right)$ & $0,05^{\mathrm{ab}}$ \\
\hline W2S1 (Waktu 12 jam + Suhu 50 C) & $0,06^{\mathrm{ab}}$ \\
\hline W3S1 (Waktu 24 jam + Suhu $50^{\circ} \mathrm{C}$ ) & $0,06^{\mathrm{ab}}$ \\
\hline W1S2 (Waktu 8 jam + Suhu $\left.70^{\circ} \mathrm{C}\right)$ & $0,06^{\mathrm{ab}}$ \\
\hline W2S2 (Waktu 12 jam + Suhu $70^{\circ} \mathrm{C}$ ) & $0,13^{\mathrm{b}}$ \\
\hline W3S2 (Waktu 24 jam + Suhu $70^{\circ} \mathrm{C}$ ) & $0,05^{\mathrm{ab}}$ \\
\hline W1S3 (Waktu 8 jam + Suhu $\left.80^{\circ} \mathrm{C}\right)$ & $0,06^{\mathrm{ab}}$ \\
\hline W2S3 (Waktu 12 jam + Suhu $80^{\circ} \mathrm{C}$ ) & $0,04^{\mathrm{a}}$ \\
\hline W3S3 (Waktu 24 jam + Suhu $80^{\circ} \mathrm{C}$ ) & $0,08^{\mathrm{ab}}$ \\
\hline
\end{tabular}

Keterangan : Nilai rata-rata yang diikuti oleh huruf yang sama menunjukkan tidak berbeda nyata dengan uji Duncan 5\%. 
Berdasarkan hasil yag ditampilkan pada Tabel 3. menunjukkan jika ratarata kadar lemak yang dihasilkan berkisar antara 0,04-0,13\%. Kadar lemak tertinggi pada perlakuan waktu pengeringan 12 jam dan suhu pengeringan $70^{\circ} \mathrm{C}$, sedangkan kadar lemak terendah pada perlakuan waktu pengeringan 12 jam dan suhu pengeringan $80^{\circ} \mathrm{C}$. Hasil penelitian ini apabila dibandingkan dengan Standar Codex (1989), belum memenuhi standar yang ditetapkan. Syarat mutu kadar lemak tepung mocaf yaitu $0,4-0,8 \%$.

Hasil penelitian ini lebih rendah dengan penelitian sebelumnya bahwa kadar lemak kue kering tepung beras dengan substitusi tepung sukun memiliki kadar lemak sebesar 16,25\%. Menurut pernyataan Oktavia (2008) bahwa lemak yang terdapat kue kering umumnya berasal dari margarin dan telur. Selaras dengan Lopulalan dkk. (2013) menyatakan bahwa kadar lemak dalam kue kering lebih banyak disumbangkan oleh margarin dan kuning telur.

Perlu adanya penurunan kadar lemak dalam tepung untuk memperpanjang umur simpan. Menurut Leufven dkk. (2007) menyatakan bahwa salah satu penyebab kerusakan bahan pangan adalah oksigen. Semua komponen gas yang terdapat dalam udara, oksigen merupakan gas yang penting ditinjau dari segi pengolahan pangan. Oksigen dapat mempercepat kerusakan lemak, yaitu dengan terjadinya ketengikan secara oksidatif pada bahan pangan yang berlemak contohnya kacang. Proses oksidasi dapat dikendalikan dengan menurunkan konsentrasi oksigen dalam kemasan Semakin sedikit volume oksigen dalam kemasan maka proses ketengikan semakin lambat.

Beberapa faktor peningkatan maupun penurunan kadar lemak dapat dihasilkan dari perombakan asam lemak pada ubi kayu yang disebabkan oleh sekresi mikroba itu sendiri. Hal itu selaras dengan pernyataan Tandrianto dkk. (2014) bahwa sebagian besar penyusun massa sel mikroba adalah protein akan tetapi juga terdapat sebagian kecil pospolipid. Hal tersebut juga didukung oleh pernyataan Kurniati (2012) bahwa kenaikan kadar lemak disebabkan karena mikroorganisme dapat memproduksi minyak mikroba selama proses fermentasi.

Mikroorganisme yang tumbuh selama fermentasi menghasilkan lipid atau lemak. Selaras dengan pernyataan Shahidi (2005) bahwa mikroorganisme menghasilkan lipid atau lemak. Minyak yang dihasilkan tersebut tidak hanya berguna untuk mikroorganisme dalam hal penggunaaan kembali dalam pemenuhan kebutuhan hidup, tetapi juga dapat dianggap sebagai sumber komoditas dari minyak. Minyak yang yang dihasilkan disebut sebagai single cell oil (SCO), yang merupakan eufemisme mirip dengan single cell protein yang biasa digunakan untuk menunjukkan protein yang berasal dari mikroorganisme sel tunggal. Menurut Prabisini (2013) bahwa waktu perendaman yang cukup lama membuat jaringan sel makin rusak dan berlubang, sehingga lemak dalam sel terdifusi keluar sel. 
Terjadi penurunan kadar lemak selama proses fermentasi. Menurut Diniyah dkk. (2018) menyatakan bahwa Penurunan kadar lemak dimungkinkan karena selama proses fermentasi mikroba membutuhkan energi yang diperoleh dari lemak. Asam laktat merupakan produk utama dari metabolisme karbohidrat oleh bakteri asam laktat tetapi konstribusinya dalam lipolisis tetap ada walaupun dalam jumlah kecil. Hasil penurunan serupa juga dibuktikan dalam fermentasi single culture tepung ubikayu, gari (fermentasi ubi kayu), dan tepung jagung terfermentasi dan tergerminasi.

\section{Kadar Protein}

Berdasarkan analisis ragam menunjukkan bahwa tidak terjadi interaksi antara perlakuan waktu dan suhu pengering dengan pengering cabinet yang digunakan terhadap kadar protein yang dihasilkan. Perlakuan waktu dan suhu pengering dengan pengering cabinet tidak berpengaruh sangat nyata terhadap kadar air yang dihasilkan.

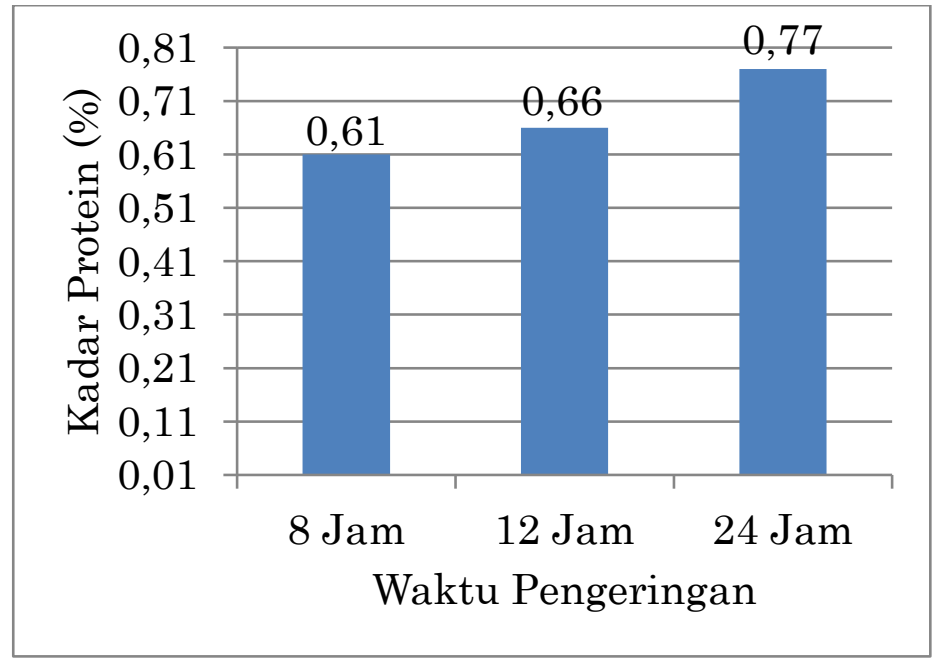

Gambar 1. Histogram Kadar Protein Mocaf Fermentasi Ragi Tape oleh Perlakuan Waktu dan Suhu Pengeringan

Berdasarkan Gambar 1 didapatkan hasil bahwa kadar protein perlakuan waktu 8 jam yaitu $0,61 \%$. Perlakuan waktu 12 jam yaitu $0,66 \%$. Perlakuan waktu 24 jam yaitu $0,77 \%$. Hasil penelitian ini apabila dibandingkan dengan Standar Codex (1989), memenuhi standar mutu yang ditetapkan. Syarat mutu kadar protein tepung mocaf maksimal $1 \%$.

Penelitian sebelumnya oleh Mahmud dkk. (2009) mengungkapkan bahwa tepung terigu memiliki kadar protein sebesar 8,9\%. Hal ini karena terigu memiliki gluten. Menurut Aptindo (2012) menyatakan bahwa Tepung terigu mengandung banyak zat pati, yaitu karbohidrat kompleks yang tidak larut dalam air. Tepung terigu juga mengandung protein dalam bentuk gluten, yang berperan dalam menentukan kekenyalan makanan yang terbuat dari bahan terigu. 
Gluten merupakan suatu jenis protein yang terdapat di dalam tepung terigu. Menurut Richana (2010) menyatakan bahwa gluten merupakan suatu jenis protein yang bersifat lengket dan elastis yang terdapat pada gandum serta hasil olahannya seperti tepung terigu. Gluten bermanfaat untuk mengikat dan membuat adonan dalam pembuatan roti menjadi elastis, sehingga mudah untuk dibentuk. Selain itu, gluten berfungsi untuk menahan udara yang masuk ke dalam adonan roti pada saat pengadukan serta gas yang dihasilkan oleh ragi pada waktu fermentasi, sehingga adonan mengembang.

Tepung yang berasal dari biji gandum ini terbilang istimewa karena mengandung gluten. Menurut Kompas (2010) menyatakan bahwa gluten adalah protein yang secara alami terkandung di semua jenis serealia atau biji-bijian yang tidak dapat larut dalam air dan bersifat elastis (lentur) sehingga mampu membentuk kerangka yang kokoh dan makanan yang kenyal pada saat dimakan. Gluten ini mengandung komponen protein yang disebut peptida. Kebanyakan orang menghindari gluten karena alasan kesehatan, terutama para penderita celiac disease (alergi terhadap protein gluten yang menyebabkan gangguan kekebalan). Ketika tepung dibasahi saat persiapan adonan, gluten mengikat sebagian air dan membentuk struktur seperti kisi-kisi. Struktur ini yang dimanfaatkan untuk memerangkap udara guna meningkatkan volume adonan pada pembuatan makanan.

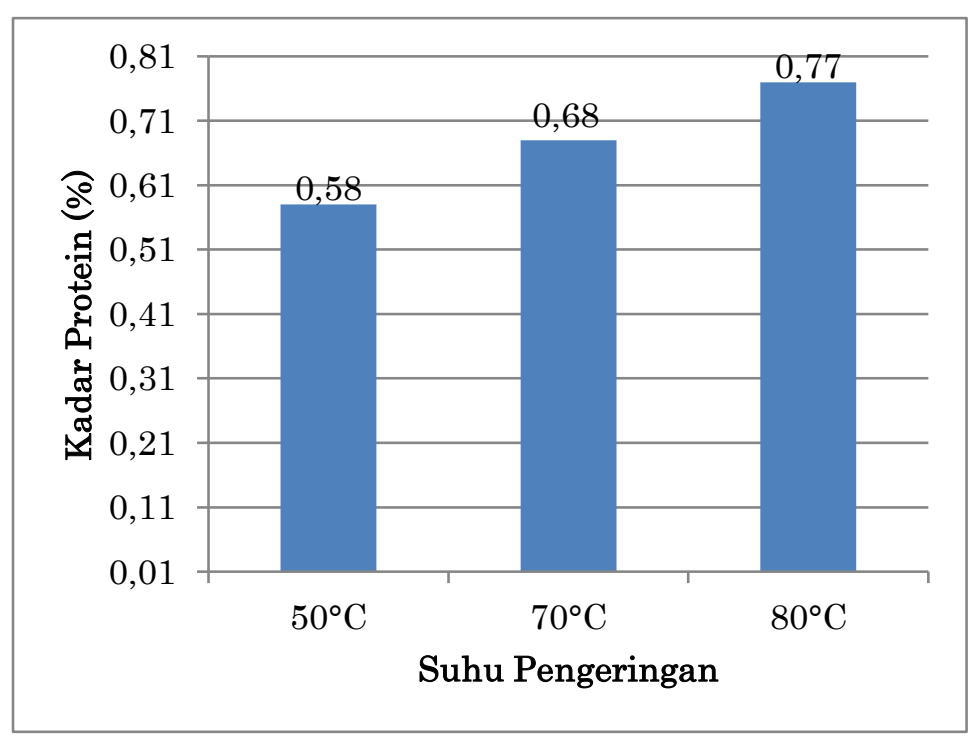

Gambar 2. Histogram Kadar Protein Mocaf Fermentasi Ragi Tape oleh Perlakuan Suhu Pengeringan

Berdasarkan Gambar 2 didapatkan hasil bahwa kadar protein perlakuan suhu $50^{\circ} \mathrm{C}$ yaitu $0,58 \%$. Perlakuan suhu $70^{\circ} \mathrm{C}$ yaitu $0,68 \%$, perlakuan suhu $80^{\circ} \mathrm{C}$ yaitu $0,77 \%$. Penelitian dapat dilihat bahwa semakin tinggi perlakuan suhu, protein yang dihasilkan semakin tinggi pula. Hal tersebut berbanding terbalik dengan pernyataan Zulfikar (2008) bahwa protein dapat mengalami denaturasi protein disebabkan oleh pemanasan, suasana asam atau basa yang ekstrim dan 
penambahan garam jenuh. Selaras dengan Syarif dkk. (2017) bahwa penurunan kadar protein dapat disebabkan oleh beberapa faktor, salah satunya adalah struktur asam amino berubah akibat pemanasan. Pemanasan dapat menyebabkan kerusakan komponen nutrisi, terutama kandungan karbohidrat dan protein. Degradasi protein dapat menyebabkan pembentukan peptida rantai pendek, asam amino dan amonia yang mudah menguap.

Faktor yang mempengaruhi kadar protein yaitu suhu pengeringan dan lama fermentasi. Menurut Kurniati dkk. (2012) menyatakan bahwa kenaikan protein disebabkan karena kemampuan bakteri dari Saccharomyces cerevisiae untuk mensekresikan bebrapa enzim ekstraseluler (protein) ke dalam ubi kayu selama proses fermentasi, atau berkembangnya Saccharomyces cerevisiae ke dalam ubi kayu dalam bentuk protein sel tunggal selama proses fermentasi. Adanya kenaikan kadar protein diperoleh dari aktivitas enzim protease yang dihasilkan oleh mikroba yang ada dalam proses fermentasi. Selaras dengan Diniyah (2018) bahwa selama fermentasi, bakteri asam laktat mampu menghidrolisis protein melalui enzim proteolitik, seperti proteinase dan peptidase, sehingga menghasilkan oligopeptida dan asam amino. Penurunan kadar protein selama fermentasi juga dibuktikan dalam fermentasi tepung ubikayu dan fermentasi sereal.

Penelitian sebelumnya menyebutkan bahwa penambahan tepung terigu dapat meningkatkan kadar protein dalam suatu produk. Menurut Nursasminto (2012) menyatakan bahwa semakin menurun proporsi tepung terigu maka kadar protein juga semakin menurun. Penambahan tepung mocaf akan menurunkan kadar protein, karena kadar protein pada mocaf sangat rendah yaitu sebesar 1\%. Hasil kadar protein yang semakin tinggi pada penelitian diduga karena adanya bahan lain yang ditambahkan pada proses pengolahan atau adanya proses fisika, kimia, atau biologi yang belum terukur

\section{Kadar Karbohidrat}

Berdasarkan analisis ragam menunjukkan bahwa terjadi interaksi antara perlakuan waktu dan suhu pengeringan dengan pengering cabinet. Perlakuan waktu dan suhu pengeringan dengan pengering cabinet tidak berbeda nyata terhadap kadar karbohidrat yang dihasilkan. Rerata kadar karbohidrat akibat waktu dan suhu pengering dengan pengering cabinet dapat dilihat pada Tabel 4 .

Berdasarkan hasil penelitian yang ditampilkan pada Tabel 4 menunjukkan jika rata-rata kadar karbohidrat yang dihasilkan berkisar 78,93-82,37\%. Kadar karbohidrat tertinggi pada waktu pengeringan 12 jam dan suhu pengeringan $70^{\circ} \mathrm{C}$ yaitu $82,37 \%$. Hasil penelitian ini lebih tinggi dibandingkan dengan penelitian sebelumnya. Penelitian sebelumnya yakni Doss dkk. (2011) menyatakan bahwa setelah perlakuan perebusan dan pengupasan kulit pada kacang koro dapat meningkatkan kadar karbohidrat. Menurut Wanjekeche (2003) melaporkan kenaikan kadar karbohidrat pada tepung dengan pengupasan kulit pada koro 
benguk putih dari 54,28\% menjadi 59,0\% dan juga sesuai dengan penelitian yang dilakukan Pangastuti dkk., (2013) pada perendaman kacang merah dengan kulit memiliki nilai karbohidrat yaitu $57,68 \%$ dan persentase karbohidrat meningkat pada perlakuan perendaman tanpa kulit yaitu $59,49 \%$.

Tabel 4. Kadar Karbohidrat Tepung Mocaf dengan Fermentasi Ragi Tape Akibat Interaksi antara Waktu dan Suhu Pengeringan dengan Pengering Kabinet

\begin{tabular}{|c|c|}
\hline Suhu dan Waktu Pengeringan & Karbohidrat (\%) \\
\hline W1S1 (Waktu 8 jam + Suhu $\left.50^{\circ} \mathrm{C}\right)$ & $79,68^{\mathrm{ab}}$ \\
\hline W2S1 (Waktu 12 jam + Suhu $\left.50^{\circ} \mathrm{C}\right)$ & $81,23^{\mathrm{gh}}$ \\
\hline W3S1 (Waktu 24 jam + Suhu $\left.50^{\circ} \mathrm{C}\right)$ & $79,78^{\mathrm{bc}}$ \\
\hline W1S2 (Waktu 8 jam + Suhu $\left.70^{\circ} \mathrm{C}\right)$ & $80,75^{\mathrm{fg}}$ \\
\hline W2S2 (Waktu 12 jam + Suhu $\left.70^{\circ} \mathrm{C}\right)$ & $82,37^{\mathrm{h}}$ \\
\hline W3S2 (Waktu 24 jam + Suhu $\left.70^{\circ} \mathrm{C}\right)$ & $80,24^{b}$ \\
\hline W1S3 (Waktu 8 jam + Suhu $\left.80^{\circ} \mathrm{C}\right)$ & $79,79^{\text {cd }}$ \\
\hline W2S3 (Waktu 12 jam + Suhu $\left.80^{\circ} \mathrm{C}\right)$ & $80,72^{\mathrm{ef}}$ \\
\hline W3S3 (Waktu 24 jam + Suhu $80^{\circ} \mathrm{C}$ ) & $78,93^{\mathrm{a}}$ \\
\hline
\end{tabular}

Keterangan : Nilai rata-rata yang diikuti oleh huruf yang sama menunjukkan tidak berbeda nyata dengan uji Duncan 5\%.

Menurut Caffall dkk. (2009) menyatakan bahwa karbohidrat merupakan sumber energi utama yang dicerna oleh tubuh manusia. Menurut Winarno (2004) menyatakan bahwa beberapa golongan karbohidrat merupakan serat (dietary fiber) yang berguna bagi pencernaan. Di dalam usus halus serat pangan tidak tecerna, dan kemudian akan masuk ke usus besar. Di dalam usus besar akan terfermentasi oleh bakteri asam laktat (BAL) menghasilkan beberapa jenis asam lemak yang berantai pendek (SCFA) yang diketahui baik mereka yang mengkonsumsinya (Damat dkk., 2019). Produk pangan yang mengandung serat pangan akan dicerna dengan lambat, sehingga dapat menurunkan kadar gula posprandian (Damat dkk., 2008). Peran penting karbohidrat dalam makanan yaitu menentukan karakteristik bahan makanan, yaitu warna, tekstur, rasa dan lainlain.

Beberapa faktor hasil kadar karbohidrat menggunakan perhitungan secara by difference dipengaruhi oleh kadar air, kadar abu, kadar lemak dan kadar protein. Hal ini sesuai dengan pernyataan Fatkurahman dkk. (2012) bahwa kadar karbohidrat dihitung secara by difference dipengaruhi oleh komponen nutrisi lain yaitu protein, lemak, air, dan abu. Hal tersebut selaras dengan pernyataan Sulistiyono (2014) bahwa proses pemanasan bahan pangan dapat meningkatkan ketersediaan karbohidrat. Menurut Sundari (2015) bahwa pemanasan yang terlalu lama akan menyebabkan penurunan senyawa antinutrisi dan proses pemanasan dapat meningkatkan ketersediaan zat gizi yang terkandung didalamnya, salah satunya yaitu karbohidrat. Selaras dengan Ranken (2000) bahwa berkurangnya air akibat proses pemanasan pada suhu tinggi dapat 
menyebabkan terjadinya peningkatan jumlah kandungan lemak, protein dan karbohidrat.

\section{Intensitas Warna}

Berdasarkan hasil analisis ragam menunjukkan bahwa terjadi interaksi antara perlakuan waktu dan suhu pengeringan menggunakan pegering cabinet yang digunakan terhadap nilai $\mathrm{L}$ dan $\mathrm{b}^{+}$, sedangkan tidak terjadi interaksi nyata antara perlakuan waktu dan suhu pengeringan menggunakan pengering cabinet yang digunakan terhadap nilai $\mathrm{a}^{+}$. secara terpisah perlakuan waktu dan suhu pengeringan menggunakan pengering cabinet berbeda nyata terhadap nilai L dan $\mathrm{b}^{+}$, akan tetapi waktu dan suhu pengering menggunakan pengering cabinet berpengaruh sangat nyata terhadap nilai $\mathrm{a}^{+}$. rerata tingkat kecerahan akibat pengaruh waktu dan suhu pengering cabinet dapat dilihat pada Tabel 5 .

Tabel 5. Intensitas Kecerahan (L) dan warna kekuningan ( $b^{+}$) Tepung Mocaf dengan Fermentasi Ragi Tape Akibat Interaksi antara Waktu dan Suhu Pengeringan dengan Pengering Kabinet

\begin{tabular}{|c|c|c|}
\hline Perlakuan Waktu dan Suhu Pengeringan & $\mathrm{L}$ & $\mathrm{b}^{+}$ \\
\hline W1S1 (waktu 8 jam + suhu $\left.50^{\circ} \mathrm{C}\right)$ & $22,80^{\mathrm{b}}$ & $+10.60^{\mathrm{abc}}$ \\
\hline W2S1 (waktu 12 jam + suhu $50^{\circ} \mathrm{C}$ ) & $11,60^{\mathrm{e}}$ & $+09,30^{\mathrm{ab}}$ \\
\hline W3S1 (waktu 24 jam + suhu $\left.50^{\circ} \mathrm{C}\right)$ & $15,95^{\mathrm{cd}}$ & $+09,65^{\mathrm{ab}}$ \\
\hline W1S2 (waktu 8 jam + suhu $\left.70^{\circ} \mathrm{C}\right)$ & $16,35^{\mathrm{c}}$ & $+10,45^{\mathrm{abc}}$ \\
\hline W2S2 (waktu 12 jam + suhu $\left.70^{\circ} \mathrm{C}\right)$ & $14,70^{\text {cde }}$ & $+10,90^{\mathrm{bc}}$ \\
\hline W3S2 (waktu 24 jam + suhu $\left.70^{\circ} \mathrm{C}\right)$ & $18,40^{\mathrm{c}}$ & $+11,25^{\mathrm{bc}}$ \\
\hline W1S3 (waktu 8 jam + suhu $\left.80^{\circ} \mathrm{C}\right)$ & $15,85^{\mathrm{cd}}$ & $+10,90^{\mathrm{bc}}$ \\
\hline W2S3 (waktu 12 jam + suhu $80^{\circ} \mathrm{C}$ ) & $12,40^{\text {de }}$ & $+08,70^{\mathrm{a}}$ \\
\hline W3S3 (waktu 24 jam + suhu $80^{\circ} \mathrm{C}$ ) & $26,90^{\mathrm{a}}$ & $+12,10^{\mathrm{c}}$ \\
\hline
\end{tabular}

Keterangan : Nilai rata-rata yang diikuti oleh huruf yang sama menunjukkan tidak berbeda nyata dengan uji Duncan 5\%.

Berdasarkan hasil penelitian yang ditampilkan pada Tabel 5 menunjukkan jika rata-rata intensitas warna (L) berkisar 11,60-26,90 dan intensitas warna $\left(\mathrm{b}^{+}\right)$ berkisar 8,70-12,10. Penelitian sebelumnya yakni Amanu dkk. (2014) menyatakan bahwa varietas ubi kayu mempengaruhi tingkat kecerahan yang dihasilkan. varietas karet dari daerah Sampang paling besar yaitu 87,6 dan terendah pada daerah Bangkalan yaitu 81,23, sedangkan untuk varietas mentega daerah paling besar berada pada Sumenep yaitu 87,33 dan paling rendah pada daerah Bangkalan yaitu 74,63.

Warna merupakan salah satu aspek yang pertama kali mempengaruhi penerimaan konsumen terhadap suatu produk selain penampakan. Menurut Eskin dkk. (2011) menyatakan bahwa warna yang kusam atau tidak sedap dipandang mata akan menimbulkan kesan negatif bagi konsumen sebelum menilai aspek yang lain. Warna bahan pangan berpengaruh pada kenampakan bahan pangan tersebut dan kemampuan dari bahan untuk memantulkan, menyebarkan, menyerap atau meneruskan sinar tampak. 
Penyebab lain peningkatan kecerahan (L), karena adanya proses perendaman. Menurut Chavez (2006) menyatakan bahwa Fermentasi yang dilakukan dengan cara perendaman menyebabkan terjadinya degradasi pigmen yang ada dalam bahan. Proses perendaman tersebut diduga dapat meluruhkan komponen yang ada dalam bahan termasuk komponen warna, semakin lama fermentasi maka semakin banyak komponen warna yang luruh sehingga tepung yang dihasilkan menjadi semakin putih. Komponen penimbul warna tersebut diduga adalah pigmen alami yang terdapat pada ubi kayu yaitu karotenoid. Karotenoid dengan jumlah kecil secara alami terdapat pada ubi kayu. Pigmen ini bertahan sampai mengalami proses pengolahan sebelum dikonsumsi

Tingkat kecerahan yang rendah diduga adanya reaksi non enzimatis yaitu reaksi maillard. Menurut Winarno (2004) bahwa reaksi Maillard terjadi bila gula pereduksi bereaksi dengan senyawa-senyawa yang memiliki gugus $\mathrm{NH}_{2}$ (protein, asam amino, dan peptida) dan terjadi bila bahan pangan dipanaskan. Ketika gula pereduksi bereaksi dengan sebuah gugus amina primer/sekunder akan membentuk suatu glukosamin maka komponen ini akan membentuk komponen berwarna gelap melanoidin yang menyebabkan perubahan warna pada bahan pangan.Selain itu, gula reduksi yang dihasilkan saat fermentasi mengalami reaksi karamelisasi yang dipengaruhi oleh waktu dan suhu saat pengeringan.

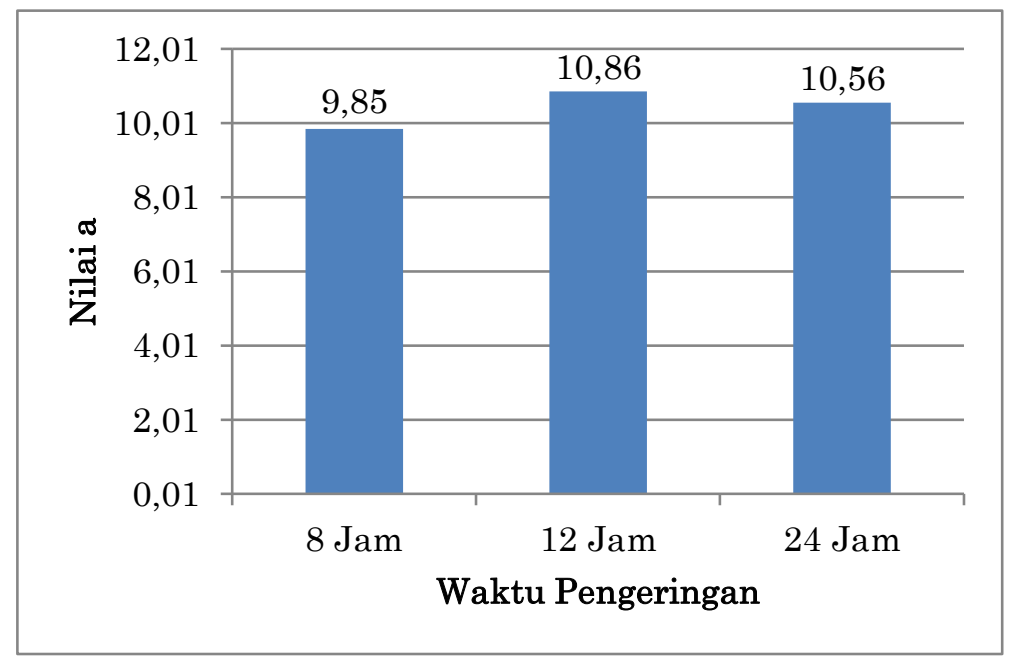

Gambar 3. Histogram Nilai a+ Mocaf Fermentasi Ragi Tape oleh Perlakuan Waktu Pengeringan

Berdasarkan Gambar 5 tersebut didapatkan hasil bahwa perlakuan waktu 8 jam memiliki nilai $\mathrm{a}^{+}$yaitu $+9,85$. Perlakuan waktu 12 jam memiliki nilai ${ }^{+}$ yaitu $+10,86$. Perlakuan waktu 24 jam memiliki nilai a ${ }^{+}$yaitu $+10,56$. Hasil penelitian sebelumnya yakni Nurdyansyah dkk. (2016) melaporkan bahwa tepung suweg dari beberapa kabupaten di Jawa Tengah memiliki jangka nilai $a^{+}$antara 2 sampai 6 . Hal ini disebabkan karena bahan baku dan perlakuan yang digunakan berbeda akan memberikan hasil yang berbeda pula. 
Hal tersebut didukung oleh bahwa karamelisasi disebabkan karena bertemunya gula reduksi dan asam amino pada suhu yang tinggi dan waktu lama. Selaras dengan Made (2016) bahwa pembentukan warna disebabkan adanya proses karamelisasi gula dan reaksi Maillard. Warna kecoklatan muncul karena adanya reaksi antara karbohidrat dengan asam amino. Selama pemanasan, gugus karbonil dari karbohidrat akan bereaksi dengan gugus amino dari asam amino atau peptide, sehingga terbentuk glikosilamin. Komponenkomponen ini selanjutnya mengalami polimerisasi membentuk komponen berwarna gelap yaitu melanoidin yang menyebabkan perubahan warna pada produk, yaitu produk akan menjadi kecoklatan.

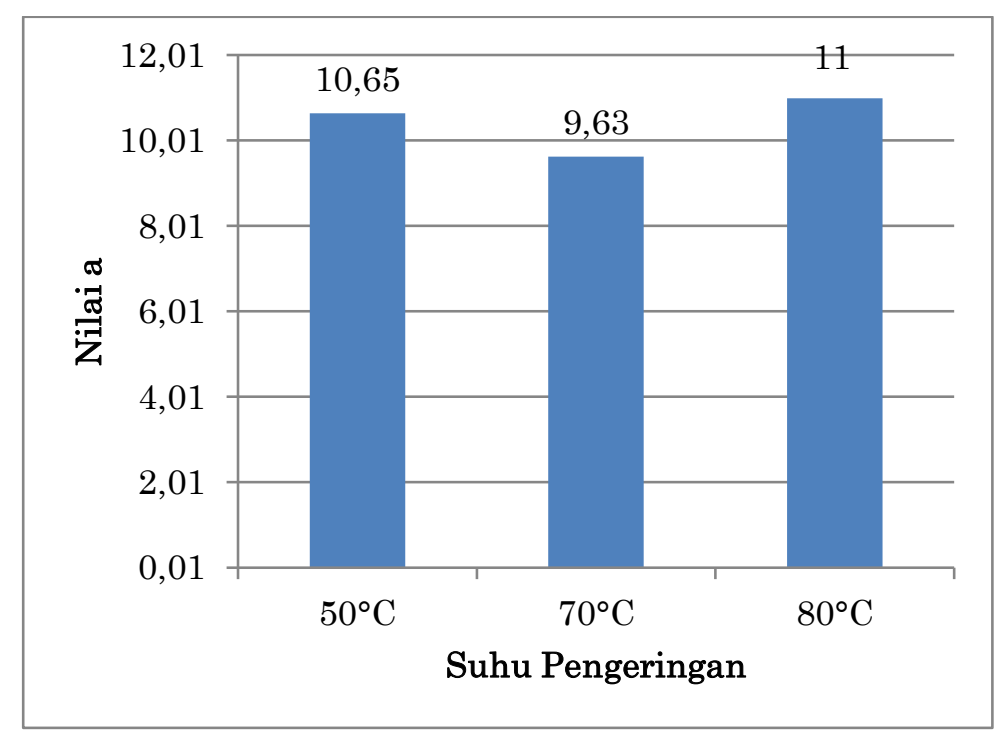

Gambar 4. Histogram Nilai $a^{+}$Mocaf Fermentasi Ragi Tape oleh Perlakuan Suhu Pengeringan

Berdasarkan Gambar 6 tersebut didapatkan hasil bahwa perlakuan suhu $50^{\circ} \mathrm{C}$ memiliki nilai $a^{+}$yaitu $+10,65$. Perlakuan suhu $70^{\circ} \mathrm{C}$ memiliki nilai a ${ }^{+}$yaitu $+9,63$. Perlakuan suhu $80^{\circ} \mathrm{C}$ memiliki nilai $\mathrm{a}^{+}$yaitu +11 . Hasil penelitian sebelumnya yakni Bernadette (2016) melaporkan bahwa nilai a ${ }^{+}$kerupuk goreng sebesar $+14,40$. Hal ini menunjukkan bahwa perlakuan yang digunakan dapat mempengaruhi hasil yang berbeda pula.

Pembentukan karamel ini membantu mempertajam warna dan menghasilkan warna kecoklatan. Selaras dengan Vaclavik dkk. (2007) bahwa pencoklatan non enzimatis seperti reaksi maillard dan karamelisasi ini sering terjadi selama pemanasan. Suhu pengeringan mempengaruhi tingkat kekuningan dari mocaf fermentasi ragi tape. Diduga suhu mempengaruhi kandungan yang terdapat di dalam bahan salah satunya yaitu kadar B-karoten. Menurut Histifarina dkk. (2004) bahwa proses pengeringan dan penepungan mengakibatkan penurunan a dan B-karoten. Selain itu, mutu produk yang dikeringkan juga dipengaruhi oleh suhu dan waktu pengeringan. Selaras dengan Ruwanti (2010) bahwa pada proses penepungan, terjadi gesekan yang terus- 
menerus antara partikel-partikel tepung ubi dengan dinding mesin penepung, sehingga menghasilkan panas yang cukup besar. Selama proses penggilingan juga terjadi kontak dengan oksigen yang tidak dapat dihindarkan keberadaanya.

\section{Penentuan Perlakuan Terbaik}

Perlakuam terbaik pada perlakuan waktu dan suhu pengeringan mocaf menggunakan metode De Garmo mendapatkan hasil terbaik berdasarkan beberapa parameter uji yang meliputi uji kadar protein, kadar air, kadar lemak, kadar abu, kadar karbohidrat, dan intensitas warna $\left(\mathrm{L}, \mathrm{a}^{+}, \mathrm{b}^{+}\right)$, yaitu terdapat pada perlakuan waktu pengeringan 8 jam dan suhu pengeringan $70^{\circ} \mathrm{C}$ dengan rerata $0,75 \%$. Metode De Garmo merupakan penentuan perlakuan paling baik dengan menggunakan metode uji indeks efektivitas yang kemudian nilai produk tiap parameter dijumlah untuk mendapatkan perlakuan terbaik (De Garmo, 1984). Rerata perlakuan terbaik pada tepung mocaf dapat dilihat pada Tabel 6 .

Tabel 6. Rerata Perlakuan Terbaik Waktu dan Suhu Pengeringan Tepung Mocaf dengan Pengering Kabinet

\begin{tabular}{lcc}
\hline Waktu dan Suhu Pengeringan & Nilai Efektivitas & Peringkat \\
\hline W1S1 (waktu 8 jam + suhu $50^{\circ} \mathrm{C}$ ) & 0,34 & 8 \\
W2S1 (waktu 12 jam + suhu $50^{\circ} \mathrm{C}$ ) & 0,42 & 6 \\
W3S1 (waktu 24 jam + suhu $50^{\circ} \mathrm{C}$ ) & 0,56 & 5 \\
W1S2 (waktu 8 jam + suhu $70^{\circ} \mathrm{C}$ ) & 0,75 & 1 \\
W2S2 (waktu 12 jam + suhu $70^{\circ} \mathrm{C}$ ) & 0,71 & 2 \\
W3S2 (waktu 24 jam + suhu $70^{\circ} \mathrm{C}$ ) & 0,66 & 3 \\
W1S3 (waktu 8 jam + suhu $80^{\circ} \mathrm{C}$ ) & 0,38 & 7 \\
W2S3 (waktu 12 jam + suhu $80^{\circ} \mathrm{C}$ ) & 0,60 & 4 \\
W3S3 (waktu 24 jam + suhu $80^{\circ} \mathrm{C}$ ) & 0,32 & 9 \\
\hline
\end{tabular}

Berdasarkan Tabel 6 menunjukkan peringkat perlakuan waktu dan suhu pengeringan tepung mocaf menggunakan pengering kabinet. Dari Hasil analisa di atas, total nilai perlakuan dari 9 perlakuan terdapat satu perlakuan terbaik yang didapatkan yaitu W1S2 (Waktu Pengeringan 8 jam dan Suhu Pengeringan $70^{\circ} \mathrm{C}$ ). Berdasarkan nilai kadar air sebesar 10,08\%, kadar protein sebesar 0,73\%, kadar lemak sebesar 0,06\%, kadar abu sebesar 8,35\%, kadar karbohidrat sebesar 80,75\%, tingkat keceraha (L) sebesar 11,6, tingkat kemerahan $\left(\mathrm{a}^{+}\right)$sebesar 3,85, serta tingkat kekuningan $\left(\mathrm{b}^{+}\right)$sebesar 9,3 .

\section{KESIMPULAN}

Berdasarkan hasil penelitian yang telah dilakukan ini data diambil kesimpulan sebagai berikut, yaitu Terjadi interaksi antara waktu dan suhu pengeringan menggunakan pengering kabinet terhadap kadar air, kadar lemak, kadar protein, kadar karbohidrat dan warna $\left(\mathrm{L}\right.$ dan $\left.\mathrm{b}^{+}\right)$. Waktu pengeringan tidak berpengaruh terhadap kadar protein dan intensitas warna $\mathrm{a}^{+}$, demikian juga suhu pengeringnya. Perlakuan waktu pengeringan 8 jam dan suhu pengeringan $70^{\circ} \mathrm{C}$ 
merupakan perlakuan terbaik yang diukur dengan uji De Garmo. Hasil uji menunjukkan bahwa perlakuan tersebut memiliki kadar air sebesar 10,08\%, kadar protein sebesar $0,73 \%$, kadar lemak sebesar 0,06\%, kadar abu sebesar 8,35\%, kadar karbohidrat sebesar 80,75\%, tingkat keceraha (L) sebesar -11,6, tingkat kemerahan $\left(\mathrm{a}^{+}\right)$sebesar 3,85, serta tingkat kekuningan $\left(\mathrm{b}^{+}\right)$sebesar 9,3.

\section{DAFTAR PUSTAKA}

Amanu, F. N., \& Susanto, W. H. 2014. Pembuatan Tepung Mocaf di Madura (Kajian Varietas dan Lokasi Penanaman) Terhadap Mutu dan Rendemen. Fakultas Teknologi Pangan. Universitas Brawijaya. Malang.

Ambarsari, I., Sarjana, \& A. Choliq. 2009. Rekomendasi Dalam Penetapan Standar Mutu Tepung Ubi Jalar. Ungaran.

[APTINDO] Asosiasi Produsen Tepung Terigu Indonesia. 2012. http://www.aptindo.or.id/index.php?option=com_content\&view=article\&i $\mathrm{d}=111$ :permintaan-terigu-terusmeningkat\&catid $=1$ :latestnew $\&$ Itemid $=50$ (diakses pada tanggal 29 Januari 2021).

Arnata, I. W., \& Anggreni, A. A. M. D. 2013. Rekayasa Bioproses Produksi Bioetanol dari Ubi Kayu dengan Teknik Ko-Kultur Ragi Tape dan Saccharomyces Cerevisiae. Teknologi Industri Pertanian Universitas Udayana. Bali.

Asrawaty. 2011. Pengaruh Suhu dan Lama Pengeringan Terhadap Mutu Tepung Pandan. Jurnal KIAT edisi Juni. Universitas Alkhairaat. Palu

Caffall KH, Mohnen D. 2009. The Structure, Function, and Biosynthesis of Plant Cell Wall Pectic Polysaccharides. Department of Biochemistry and Molecular Biology and Complex Carbohydrate Research Center. University of Georgia. United States.

Chavez, A. L. Sanchez, T. Ceballos, H. Rodrigues-Amaya, D.B. Nestel, P. Tohme, J. Ishitani, M. 2006. Retention of Carotenoids in Cassava Roots Submitted to Different Processing Methods. Colombia: John Wiley \& Sons, Inc.

[CODEX STAN] Codex Alimentarius Commision. 1995. Edible Cassava Flour (CODEX STAN 176-1989 Rev. 1 - 1995). Codex Alimentarius Commision. United State of America.

Damat, D., Marsono, Y. Haryadi dan Cahyanto, M. N. 2008. Efek Hipokolesterolemik dan Hipoglikemik Pati Garut Butirat pada Tikus Sprague Dawley. Jurnal Farmasi Indonesia, 19(3), pp.109-116.

Damat, D., Anggriani, R., Setyobudi, R.H., Soni, P. 2019. Dietary Fiber and Antioxidant Activity of Gluten-Free Cookies with Coffee Cherry Flour Addition. Coffee Science. 14(4), pp.493-500. DOI:http://dx.doi.org/10.25186/cs.v14i4.1625

De Garmo. 1984. Materials and Processes in Manufacture, Edisi ke 7. Jakarta: PT Pradaya Paramita. 
Diniyah, N. Yuwana, N. Purnomo, B. H., Maryanto N. F. N., dan Subagio, A. 2018. Karakteristik Sera Mocaf (Modified Cassava Flour) dari Ubi Kayu Varietas Manis dan Pahit. Jurnal Penelitian Pasca Panen Pertanian. Jurusan Teknologi Hasil Pertanian. Fakultas Teknologi Hasil Pertanian. Universitas Jember. Jember.

Doss, A., M. Pugalenthi, and V. Vadivel. 2011a. Nutritional evaluation of wild jackbean (Canavalia ensiformis) seeds in different locations of South India. World Appl. Sci. J. 13(7), pp. 1606-1612

Fatkurahman, R. Atmaka, W., dan Basito, B. 2012. Karakteristik Sensori dan Sifat Fisikokimia Cookies Dengan Substitusi Bekatul Beras Hitam (Oryza sativa L.) dan Tepung Jagung (Zea mays L.). Jurnal Teknosains Pangan. Jurusan Ilmu dan Teknologi Pangan. Universitas Sebelas Maret. Surakarta.

Histifarina, D. Musaddad, D. dan Murtiningsih, E. 2004. Teknik Pengeringan dalam Oven untuk Irisan Wortel Kering Bermutu. Balai Penelitian Tanaman Sayuran. Jurnal Hortikultura. Bandung.

Joko, N. W. K., Primawati, Y. F., Nursigit, B. 2012. Proses Pengeringan Singkong (Manihot esculenta Crantz) Parut Dengan Menggunakan Pneumatic Driyer. Seminar Nasional. Universitas Udayana. Denpasar.

Kompas. 2010. Jenis Makanan yang Mengandung Gluten. Tersedia di https://lifestyle.kompas.com/read/2010/01/25/12000912/jenis.makanan.y ang .mengandung.gluten. Diakses pada tanggal 27 Januari 2021.

Kurniati I. L, Alda S, Gunawan dan Twidjaya. 2012. Pembuatan Mocaf (modified cassava flour) dengan Proses Fermentasi menggunakan Lactobacsilis plantarum, Saccharomyces cereviseae dan Rhizopuz oryzea. Skripsi. Institut Teknologi Sepuluh Nopember. Surabaya.

Leufven, A., Sedaghat, N. dan Habibi, M. B. 2007. Influence of different packaging systems on stability of raw dried pistachio nuts at various conditions. Iranian Food Science and Technology Research Journal. Departmen of Food Science and Technology. Ferdowsi University. Iran.

Lidiasari, E., Syafutri, M. I., dan Syaiful, F. 2006. Pengaruh Perbedaan Suhu Pengeringan Tepung Tapai Ubi Kayu Terhadap Mutu Fisik dan Kimia yang Dihasilkan. Jurnal Ilmu-Ilmu Pertanian Indonesia. Jurusan Teknologi Pertanian. Fakultas Pertanian.Universitas Sriwijaya. Sumatera Selatan.

Lisa, M., Lutfi, M., dan Susilo, B. 2015. Pengaruh suhu dan lama pengeringan terhadap mutu tepung jamur tiram putih (Plaerotus ostreatus). Jurnal Keteknikan Perntanian Tropis dan Biosistem, 3.

Lopulalan C. G.CH, Mailoa M, Sangadji D. 2013. Kajian Formulasi Penambahan Tepung Ampas Tahu terhadap Sifat Organoleptik dan Kimia Cookies. Fakultas Pertanian. Universitas Patimura. Ambon. 
Lubis, Y. M., Rohaya, S., dan Dewi, H. A. 2012. Pembuatan Meuseukat Menggunakan Tepung Komposit dari Suku (Artocarpus altilis) dan Terigu serta Penambahan Nenas (Ananas comosus L.). Jurnal Teknologi dan Industri Pertanian Indonesia. Aceh.

Made, A. 2016. Proses Pencoklatan (Browning Process) pada Bahan Pangan. Jurusan Kimia. Fakultas Matematika dan Ilmu Pengetahuan Alam. Universitas Udayana. Denpasar.

Mahmud M. K., Hermana, N. A. Zulfianto, R. R. Apriyantono, I. Ngadiarti, B. Hartati, Bernadus, dan Tinexcelli. 2009. Tabel Komposisi Pangan Indonesia (TKPI). Jakarta: PT. Elex Media Komputindo.

Muntikah, dan Razak, M. 2017. Bahan Ajar Gizi Ilmu Teknologi Pangan. Kementerian Kesehatan Republik Indonesia. Jakarta.

Nurdyansyah, F., Hasbullah, U. H. A., dan Supriyadi, B. 2016. Karakter Warna Tepung Umbi Suweg (Amorphophallus Campamulatus BI) di Jawa Tengah. Seminar Nasional Hasil Penelitian. Lembaga Penelitian dan Pengabdian Kepada Masyarakat. Universitas PGRI Semarang. Semarang.

Nursasminto, R. P. 2012. Pengaruh Proporsi Penggunaan Tepung Komposit (Terigu, Mocaf, Edamame) terhadap Sifat Fisik Kimia dan Organoleptik Mie Kering. Skripsi. Teknologi Hasil Pertanian. Fakultas Teknologi Pertanian. Universitas Brawijaya. Malang.

O'Kelly, B. 2004. Accurate Determination of Moisture Content of Organic Soils Using the Oven Drying Method. Drying Technology. Dry Technol Journal, 22, pp. 1767-1776. DOI: 10.1081/DRT-200025642.

Oktavia, R. D. 2008. Evaluasi Produk Good Time Cookies di PT. Arnott's Indonesia sebagai Dasar Penentuan Nilai Tambah Produk. Skripsi. Departemen Ilmu dan Teknologi Pangan Fakultas Teknologi Pertanian Insititut Pertanian Bogor. Bogor.

Rahmawati Rahmawati, A., 2010. Pemanfaatan Limbah Kulit Ubi Kayu (Manihot utilissima Pohl.) dan Kulit Nanas (Anana comusus L.) pada Produksi Bioetanol menggunakan Aspergillus niger. Skripsi. Universitas Sebelas Maret Surakarta. Surakarta

Ranken, M.D. 2000. Handbook of Meat Product Technology. Oxford: Blackwell Science Ltd

Richana, N. 2010. Tepung Jagung Termodifikasi Sebagai Pengganti Terigu. Warta Penelitian dan Pengembangan. Bogor

Rijal, M., Natsir, N. A., dan Sere, I. 2019. Analisis Kandungan Zat Gizi pada Tepung Ubi Ungu (Ipomea batatas var Ayumurasaki) dengan Pengeringan Sinar Matahari dan Oven. Skripsi. Fakultas Ilmu Tarbiyah dan Keguruan IAIN Ambon. Ambon

Ruwanti, S. 2010. Optimasi Kadar B-Karoten Pada Proses Pembuatan Tepung Ubi Jalar Oranye (Ipomoea batatas L) Dengan Menggunakan Response 
Surface Methodology (RSM). Fakultas Pertanian Universitas Sebelas Maret. Surakarta

Shahidi, F. 2005. Bailey's Industrial Oil and Fat Products Edible Oil and Fat Product 6th Edition. Processing Technologies. ISBN: 978-0471-38460-1. Department of Biochemistry. Memorial University of Newfoundland: Canada

[SNI] Standar Nasional Indonesia. 2011. Mocaf. SNI 7622-2011. Jakarta.

Sudarmadji, S. 2003. Mikrobiologi Pangan. PAU Pangan dan Gizi Universitas Gajah Mada. Yogyakarta

Sulistiyono, A. 2014. Penentuan Jenis Karbohidrat Dengan Uji Kualitatif Menggunakan Reagen pada Sampel Mie Instan. Industri Pangan. Universitas Pembangunan Nasional Veteran. Surabaya.

Sundari, D. 2015. Pengaruh Proses Pemasakan terhadap Komposisi Zat Gizi Bahan Pangan Sumber Protein. Jakarta: Media Litbangkes.

Suprapti, M. L. 2001. Membuat Aneka Olahan Nanas. Jakarta: Puspa Swara. Syarif, W. Holinesti, R. Faridah, A. dan Fridayati, L. 2017. Analisis Kualitas Sala Udang Rebon. Andalas Agricultural Technology Journal, 21(1)

Tandrianto, J., Mintoko, D. K., dan Gunawan, S. 2014. Pengaruh Fermentasi pada Pembuatan Mocaf (Modified Cassava Flour) dengan Menggunakan Lactobacillus plantarum terhadap Kandungan Protein. Jurnal Teknik Pomits, 3(2)

Taufiq, M. 2004. Pengaruh Temperatur Terhadap Laju Pengeringan Jagung Pada Pengeringan Konvensional dan Fluidized Bed. Skripsi. Fakultas Teknik, Universitas Sebelas Maret. Surakarta.

Vaclavik, V dan Christian, E. W. 2007. Essentials of Food Science. New York: Springer

Wanjekeche, E., Wakasa, V., dan Mureithi, J. G. 2003. Effect of Germination, Alkaline and Acid Soaking and Boiling on The Nutritional Value of Mature and Immature Mucuna (Mucuna pruriens) Beans. Tropical and Subtropical Agroecosystem, pp. 183 - 192. DOI : 10.1.1.602.7903

Winarno, F.G. 2004. Kimia Pangan dan Gizi. Jakarta: Gramedia Pustaka Utama.

Zulfikar. 2008. Kimia Kesehatan Jilid 3. Jakarta: Departemen Pendidikan Nasional 